ANDRZEJ TOKARSKI

Wyżzza Szkoła Bankowa, Toruń, Polska - WSB University in Torun, Poland

MACIEJ TOKARSKI

Wyższa Szkoła Bankowa, Toruń, Polska - WSB University in Torun, Poland

\title{
Przebieg procesu upadłościowego przedsiębiorstw polskich w XXI w.
}

\section{The Course of the Bankruptcy Process of Polish Enterprises in the 21st Century}

Streszczenie: Problematyka upadłości przedsiębiorstw stanowi szczególny obszar zainteresowania nauki i praktyki gospodarczej ze względu na wysokie koszty ekonomiczne i społeczne związane z tym zjawiskiem. Upadłości przedsiębiorstw stanowią stały element systemu gospodarczego każdego kraju o gospodarce rynkowej. Są one bardzo złożonymi procesami o podłożu ekonomicznym, prawnym, psychologicznym i społecznym. Wywołują skutki, które dotyczą różnych składników życia gospodarczego. W artykule zaprezentowano dane liczbowe pokazujące skalę i charakter upadłości biznesowych, które są nierozerwalnie związane z gospodarką rynkową i występują we wszystkich systemach respektujących zasady gospodarki rynkowej. W opracowaniu autorzy dokonali analizy zjawiska upadłości przedsiębiorstw w Polsce w latach 2001-2018, z uwzględnieniem obowiązujących regulacji prawnych, które miały wpływ na rodzaje obowiązujących postępowań upadłościowych i spowodowały od 2016 r., wskutek wejścia w życie Prawa restrukturyzacyjnego, zmniejszenie postępowań upadłościowych (likwidacyjnych) oraz wzrost postępowań restrukturyzacyjnych.

\begin{abstract}
The issue of bankruptcy of enterprises constitutes a particular area of interest for science and business practice due to the high economic and social costs associated with this phenomenon. The bankruptcies of enterprises are a permanent component of the economic system of any country with free market economy. They are very complex processes with economic, legal, psychological and social basis. They evoke effects that affect various components of the economic life. The article presents numerical data showing the scale and nature of business bankruptcies that are inextricably linked to the market economy and occur in all systems which follow the principles of the market economy. In the paper the authors analysed the phenomenon of bankruptcy of enterprises in Poland in the years 2000-2018 taking into account the applicable legal regulations that affected the types of bankruptcy proceedings in force and which since 2016 have resulted in both the reduction of bankruptcy proceedings (liquidation proceedings) due to the entry into force of the Restructuring Law, as well as the increase in the restructuring proceedings.
\end{abstract}


Słowa kluczowe: niewypłacalność; regulacje prawne w zakresie upadłości i restrukturyzacji; upadłość; upadłość przedsiębiorstw w polskiej gospodarce

Keywords: bankruptcy, bankruptcy of enterprises in the Polish economy; insolvency; legal regulations regarding bankruptcy and restructuring in the Polish economy

Otrzymano: 22 kwietnia 2019

Received: 22 April 2019

Zaakceptowano: 12 sierpnia 2019

Accepted: 12 August 2019

\section{Sugerowana cytacja/Suggested citation:}

Tokarski, A., Tokarski, M. (2019). Przebieg procesu upadłościowego przedsiębiorstw polskich w XXI w. Przedsiębiorczość - Edukacja [Entrepreneurship - Education], 15(2), 248-263. doi: $10.24917 / 20833296.152 .17$

\section{Wstęp}

Upadłości przedsiębiorstw stanowią stały element systemu gospodarczego każdego kraju o gospodarce rynkowej. Są one bardzo złożonymi procesami o podłożu ekonomicznym, prawnym, psychologicznym i społecznym. Wywołują skutki, które dotyczą różnych składników życia gospodarczego. Należą do nich przede wszystkim: utrata środków zainwestowanych przez udziałowców i kredytodawców w dane przedsięwzięcie, możliwość znacznego pogorszenia się sytuacji finansowej lub utraty płynności finansowej innych firm powiązanych z upadającym przedsiębiorstwem (tzw. domino upadłości), a czasem także wzrost bezrobocia $\mathrm{w}$ regionie, jeśli bankrutująca firma była w nim dominującym pracodawcą. Upadłość odgrywa jednak również w gospodarce ważną rolę polegającą na eliminowaniu przedsiębiorstw, które nie działają w efektywny sposób i nie są w stanie funkcjonować w warunkach konkurencji. Ważne jest, aby proces tej eliminacji przebiegał w sposób, który zapewni ograniczenie zjawiska domina upadłości, a inwestorom umożliwi odzyskanie zaangażowanych w bankrutującą firmę środków i ulokowanie ich w bardziej efektywny sposób. Dlatego, w większości krajów na świecie, ustanawia się prawo upadłościowe, które reguluje proces upadłości przedsiębiorstw.

Z początkiem 2016 r. w Polsce weszło w życie Prawo restrukturyzacyjne, jednocześnie zostało znowelizowane obowiązujące dotychczas Prawo upadłościowe i naprawcze (obowiązywało od 28/02/2003 do 31/12/2015 r.). W rezultacie, od początku 2016 r. obowiązują dwie odrębne ustawy regulujące dwa rodzaje postępowań wobec podmiotów gospodarczych mających trudności z regulowaniem zobowiązań: Ustawa prawo upadłościowe $z$ dnia 15.05.2015 r. (Dz.U. z 2015 r., poz. 233) oraz Ustawa $z$ dnia 15.05.2015 r. Prawo restrukturyzacyjne (Dz.U. z 2015 r., poz. 978).

Celem artykułu jest przeanalizowanie zjawiska upadłości przedsiębiorstw w Polsce w latach 2001-2018. Wyznaczony cel realizowany jest przez sformułowanie odpowiedzi na następujące pytania badawcze:

- Jaki był wpływ regulacji prawnych dotyczących upadłości i restrukturyzacji w gospodarce polskiej w latach 2001-2018 w zakresie kształtowania się struktury rodzajowej postępowań upadłościowych?

- Jaki był udział postępowań restrukturyzacyjnych w latach 2001-2015 oraz 2016-2018 w stosunku do ogółu liczby upadłości w polskiej gospodarce? 
- Jaki był wpływ zmiany przepisów prawa upadłościowego na liczbę i strukturę rodzajową upadłości przedsiębiorstw w polskiej gospodarce - postępowań likwidacyjnych w relacji do postępowań restrukturyzacyjnych po 2016 r.?

Artykuł ma charakter teoretyczno-empiryczny. Wykorzystane metody badawcze to analiza literatury przedmiotu oraz przepisów prawa dotyczących upadłości w Polsce, a także analiza danych statystycznych dotyczących upadłości przedsiębiorstw w Polsce w latach 2001-2018. W artykule przyjęto hipotezę badawczą, iż liczba i struktura rodzajowa upadłości przedsiębiorstw w polskiej gospodarce w latach 2001-2018 uległa zmianie na skutek zmiany przepisów prawa, które nastąpiły z początkiem $2016 \mathrm{r}$. W artykule podjęto próbę weryfikacji tej hipotezy na poziomie polskiej gospodarki.

\section{Przegląd literatury przedmiotu}

Problematyka upadłości przedsiębiorstw stanowi istotny obszar badań empirycznych, co potwierdzają liczne opracowania naukowe (Tokarski, A., 2018). Przeprowadzono wiele badań empirycznych i teoretycznych w dziedzinie upadłości i niewypłacalności podmiotów gospodarczych w różnych dekadach i w różnych krajach oraz analizy różnych sektorów gospodarki, co prowadziło do uzyskania do różnych wniosków. Badania dotyczące upadłości zostało przeprowadzone w kilku obszarach i różnych podejściach (Hart, 2000, Wang, 2006).

Według Wanga badania naukowe dotyczące zjawiska upadłości koncentrują się na (Wang, 2006):

- zmianach dotyczących ładu korporacyjnego w aspekcie zagrożenia upadłością (np. Eckbo i in., 2003; Franks, Sussman, 1999; Gilson, 1990; White, 1989),

- kosztach bankructwa (np. Altman, 1984; Lubben, 2000; Bris, Welch, Zhu, 2006; Warner, 1977; Weiss, 1990),

- cenach akcji i długoterminowych wynikach (np. Altman, Eberhart, Aggarwal 1999; Gilson, 1997; Gilson, Kose, Lang, 1990; Hotchkiss, 1995),

- zmianach regulacji prawnych dotyczących upadłości (np. Aghion, Hart, Moore, 1992; Bebchuk, Frank, Tourous, 1989; Claessens, Klapper, 2006; Eberhart, More, Roenfeldt, 1990; Hartetal, 1997; Routlgde, Gadenne, 2000),

- przewidywaniach upadłości przedsiębiorstw (np. Altman, 1968; Beaver, 1966, 1968; Beaver i in., 2005; Bernhardsen, 2005; Campbell, 1996, 2002; Ohlson, 1980) oraz przyczynach upadłości (np. Altman, 1986; Altman, Hotchkiss, 2006; Ooghe, Prijcker, 2006, 2008).

Stosunkowo niedawno w literaturze polskiej pojawił się interdyscyplinarny nurt rozważań skoncentrowany na analizie teoretycznych i empirycznych aspektów upadłości przedsiębiorstw. Został on wprowadzony i jest intensywnie rozwijany przez zespół badaczy skupionych wokół prof. E. Mączyńskiej ze Szkoły Głównej Handlowej w Warszawie (Babiarz-Mikulska, Czapracka, Morawska, 2012; Mączyńska, 2005, 2008, 2009, 2010, 2013, 2014, 2015; Mączyńska, Adamska, 2013; Mączyńska, Kuciński, 2008; Mączyńska, Morawska, 2015; Morawska 2011, 2013). W nurcie analiz ekonomicznych mieszczą się prace nad zjawiskiem, przyczynami i ekonomiczno-społecznymi konsekwencjami upadku przedsiębiorstw, zarówno w ujęciu historycznym, jak i przestrzennym (Antonowicz, 
2015; Tokarski, A., Tokarski, M., 2018; Tomczak, 2018)ํ․ Istotnym źródłem są regulacje prawne w zakresie prawa upadłościowego.

Regulacje prawne w zakresie upadłości i restrukturyzacji w gospodarce polskiej

Z początkiem 2016 r. w Polsce weszło w życie Prawo restrukturyzacyjne, jednocześnie zostało znowelizowane obowiązujące dotychczas Prawo upadłościowe i naprawcze. W rezultacie, tak jak powiedziano we wstępie, od początku 2016 r. obowiązują dwie odrębne ustawy regulujące dwa rodzaje postępowań wobec podmiotów gospodarczych mających trudności z regulowaniem zobowiązań to jest (Banasik, Morawska, 2016):

- Ustawa Prawo upadłościowe z dnia 15.05.2015 r. (Dz.U. z 2015 r., poz. 233).

- Ustawa z dnia 15. 05.2015 r. Prawo restrukturyzacyjne (Dz.U. z 2015 r., poz. 978).

$\mathrm{Z}$ dużym uproszczeniem można przyjąć, że Prawo restrukturyzacyjne służy ratowaniu, a prawo upadłościowe - likwidacji przedsiębiorstwa dłużnika (Hrycaj, 2015).

Podstawowym założeniem wprowadzonych zmian była potrzeba usunięcia zjawiska stygmatyzacji dłużnika już z samego powodu wszczęcia przez niego postępowania upadłościowego, chociażby w opcji układowej, oraz potrzeba wyeliminowania niebezpieczeństwa wdrożenia przez sąd upadłości likwidacyjnej na skutek wniosku dłużnika, który żądał jednak restrukturyzacji w ramach upadłości w opcji układowej (Horobiowski, 2016).

Zasadniczą wprowadzoną zmianą pozostaje rozdzielenie postępowań upadłościowych, nastawionych na likwidację majątku od postępowań restrukturyzacyjnych, w których dąży się do utrzymania działalności przedsiębiorstwa (Prawo..., 2011). Rozdzielenie stworzyło czytelne ramy dla stron procesu, przypominające pod kątem konstrukcji rozwiązania ze Stanów Zjednoczonych (Chapter 7 - upadłość i Chapter 11 - restrukturyzacja; White, 1989).

W zakresie rodzajów czy przebiegu postępowań zmiany legislacyjne wprowadzają swoistą rewolucję w postępowaniach restrukturyzacyjnych. I tak jak obecnie postępowanie upadłościowe jest $\mathrm{w}$ dużej mierze tożsame $\mathrm{z}$ upadłością likwidacyjną sprzed zmian prawa, tak strony procesów restrukturyzacyjnych mogą wykorzystywać poza postępowaniami układowymi dwa całkowicie nowe postępowania - o zatwierdzenie układu oraz sanacyjne (Krajewski, Matuszak, Tokarski, 2017).

Prawo restrukturyzacyjne wraz z prawem upadłościowym mają tworzyć spójny system regulacji (rycina 1 ).

Dłużnik potencjalnie zagrożony upadłością, a chcący jej uniknąć, może z własnej inicjatywy podjąć próbę restrukturyzacji. Trzeba jednak pamiętać, że w trakcie postępowania restrukturyzacyjnego nie można ogłosić upadłości firmy.

Ustawa Prawo restrukturyzacyjne zmienia diametralnie podejście do przedsiębiorcy przeżywającego problemy finansowe (Wieczerzyńska, 2015a). Wprowadza ona cztery postępowania restrukturyzacyjne (zob. tabele 1 i 2 ), w tym jedno sanacyjne, oraz zmienia definicję upadłości przedsiębiorcy. Nowe przepisy zostały opracowane z myślą o usprawnieniu postępowań i rozszerzeniu możliwości restrukturyzacji oraz z naciskiem

\footnotetext{
${ }^{1}$ Ze względu na obszerność artykułu autorzy nie definiują pojęcia oraz przyczyn upadłości przedsiębiorstw, które w sposób szczegółowy opisują m.in.: Rogowski (2015a, b), Hołda, Strojny (2019), Kuciński (2005), Szczerbak (2007).
} 
Rycina 1. Drzewo decyzyjne postępowań upadłościowych i restrukturyzacyjnych

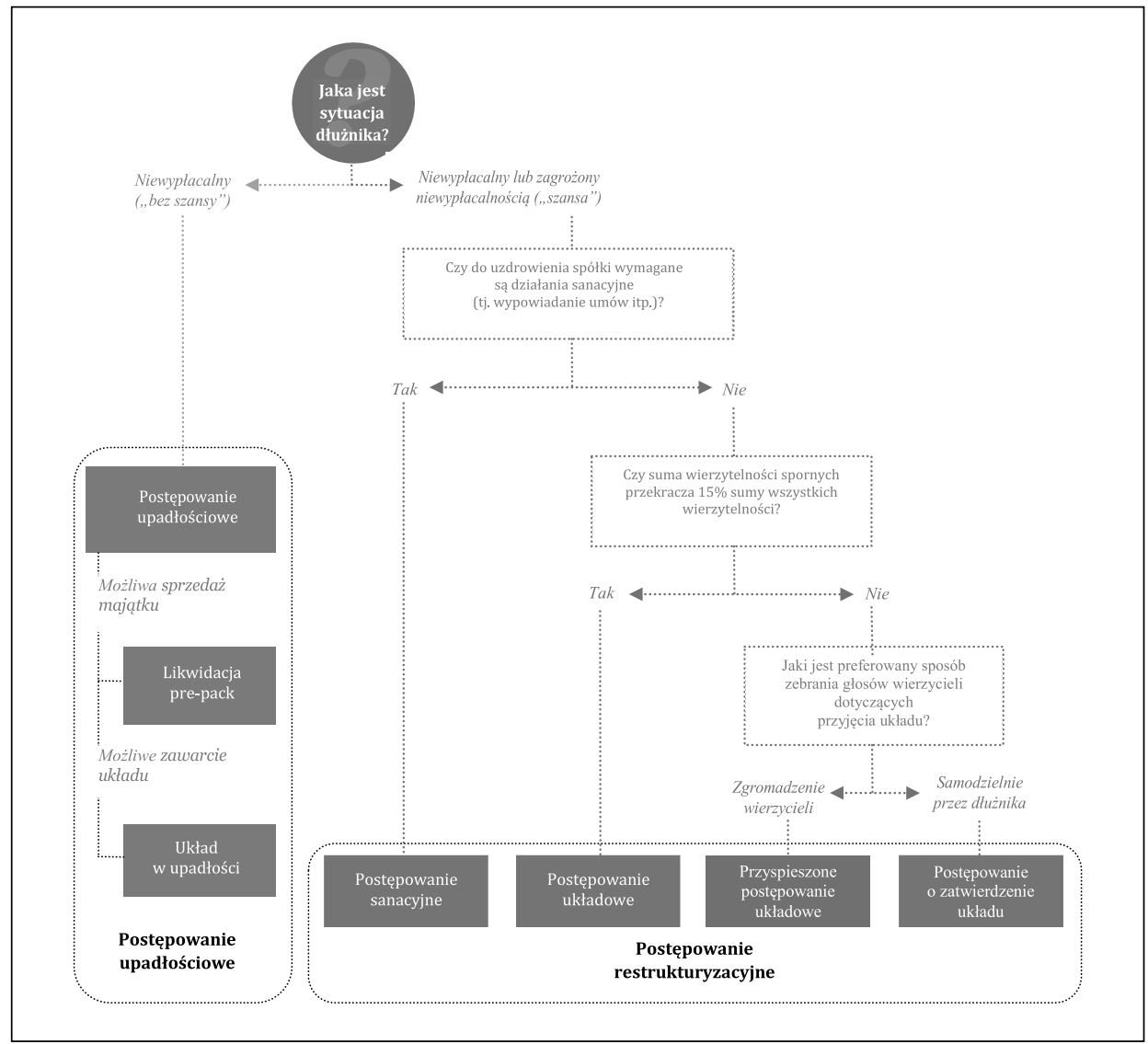

Źródło: Upadłości i restrukturyzacje w Polsce... (2017: 8)

na zapobieganie likwidacji i utrzymanie funkcjonowania przedsiębiorstwa doświadczającego trudności finansowych oraz utrzymanie jego działalności.

Tabela 1. Postępowanie restrukturyzacyjne zapisane w Prawie restrukturyzacyjnym

\begin{tabular}{|c|c|}
\hline $\begin{array}{c}\text { Rodzaj } \\
\text { postępowania }\end{array}$ & Główne założenia \\
\hline $\begin{array}{l}\text { Postępowanie } \\
\text { o zatwierdzenie } \\
\text { układu }\end{array}$ & $\begin{array}{l}\text { - samodzielne zbieranie głosów wierzycieli przez dłużnika bez udziału } \\
\text { sądu } \\
\text { - aktywne negocjacje z wierzycielami i przedstawienie ich wyników } \\
\text { sądowi } \\
\text { - samodzielnie wybieranie przez dłużnika licencjonowanego doradcy } \\
\text { restrukturyzacyjnego, który weryfikuje propozycje układowe } \\
\text { pod względem prawnym i formalnym }\end{array}$ \\
\hline $\begin{array}{l}\text { Przyspieszone } \\
\text { postępowanie } \\
\text { układowe }\end{array}$ & $\begin{array}{l}\text { - sporządzenie przez dłużnika spisu wierzytelności } \\
\text { - zwołanie przez sąd zgromadzenia wierzycieli } \\
\text { - zatwierdzenie wierzytelności w trybie uproszczonym } \\
\text { - zawieszenie egzekucji wierzytelności objętych układem (zabezpieczenie } \\
\text { majątku dłużnika) }\end{array}$ \\
\hline
\end{tabular}




\begin{tabular}{|c|c|}
\hline $\begin{array}{l}\text { Postępowanie } \\
\text { układowe }\end{array}$ & $\begin{array}{l}\text { - sporządzenie przez dłużnika spisu wierzytelności } \\
\text { - zwołanie przez sąd zgromadzenia wierzycieli } \\
\text { - zatwierdzenie wierzytelności w trybie uproszczonym } \\
\text { - pozostawienie dłużnikowi zarządu majątkiem } \\
\text { - objęcie układem zobowiązań wobec ZUS }\end{array}$ \\
\hline $\begin{array}{l}\text { Postępowanie } \\
\text { sanacyjne }\end{array}$ & $\begin{array}{l}\text { - wniosek o otwarcie postępowania sanacyjnego składa dłużnik } \\
\text { lub wierzyciel, a w szczególnych przypadkach kurator } \\
\text { - restrukturyzacji podlegają zobowiązania, majątek i zatrudnienie } \\
\text { - postępowaniem kieruje i sprawuje nad nim restrykcyjny nadzór sędzia } \\
\text { komisarz } \\
\text { - następuje zabezpieczenie majątku dłużnika przez ustanowienie } \\
\text { - tymczasowego nadzorcy sądowego (ograniczenia w zarządzaniu } \\
\text { majątkiem) lub zarządcy masy sanacyjnej (pozbawienie dłużnika praw } \\
\text { do zarządzania majątkiem) } \\
\text { - plan sanacyjny sporządza nadzorca sądowy lub zarządca masy } \\
\text { wspólnie z dłużnikiem } \\
\text { - następuje wygaśnięcie pełnomocnictw udzielonych przez dłużnika oraz } \\
\text { zawieszenie egzekucji z majątku wchodzącego w skład masy sanacyjnej } \\
\text { - zakaz obciążania majątku w celu zabezpieczenia wierzytelności } \\
\text { powstałej przed otwarciem postępowania } \\
\text { - prowadzenie postępowań sądowych i administracyjnych wyłącznie } \\
\text { przez zarządcę } \\
\text { - zakaz wypowiadania dłużnikowi umów najmu, leasingu, ubezpieczeń, } \\
\text { pożyczki itp. }\end{array}$ \\
\hline
\end{tabular}

Źródło: Famielec, Kożuch (2018: 71-72)

Tabela 2. Zalety i wady postępowań restrukturyzacyjnych z perspektywy dłużnika i wierzyciela

\begin{tabular}{|c|c|}
\hline \multicolumn{2}{|c|}{ Postępowania o zatwierdzenie układu } \\
\hline Zalety & Wady \\
\hline $\begin{array}{l}\text { - Możliwość samodzielnego zbierania głosów } \\
\text { wierzycieli przez dłużnika bez udziału sądu. } \\
\text { Dłużnik przedstawia wierzycielom karty do } \\
\text { głosowania, zawierające określone sposo- } \\
\text { by restrukturyzacji zadłużenia (propozycje } \\
\text { układowe). Głosy zbierane są w formie pi- } \\
\text { semnej bez konieczności udziału notariusza } \\
\text { - Pozostawienie dłużnikowi uprawnienia } \\
\text { do zarządzania majątkiem i dokonywania } \\
\text { wszelkich czynności zarządu, również czyn- } \\
\text { ności przekraczających zarząd zwykły } \\
\text { - Postępowanie jest poufne na etapie przedsá- } \\
\text { dowym, zaś etap sądowy trwa bardzo krótko. } \\
\text { Postępowanie pozwala zminimalizować ne- } \\
\text { gatywny przekaz rynkowy związany z kryzy- } \\
\text { sem finansowym } \\
\text { - Postępowanie daje możliwość indywidula- } \\
\text { nych negocjacji poza rygorami postępowa- } \\
\text { nia sądowego oraz bez zabezpieczenia ma- } \\
\text { jątku dłużnika }\end{array}$ & $\begin{array}{l}\text { - Główną wadą jest brak ochrony majątku } \\
\text { dłużnika przed windykacją. W postępowa- } \\
\text { niu o zatwierdzenie układu nie stosuje się } \\
\text { przepisów o zabezpieczeniu, zatem nie moż- } \\
\text { na zawiesić egzekucji ani też uchylić zajęć } \\
\text { rachunków bankowych. Oznacza to, że do } \\
\text { momentu zatwierdzenia układu wierzyciel } \\
\text { może egzekwować swoje należności bez } \\
\text { ograniczeń. Dopiero po zatwierdzeniu ukła- } \\
\text { du prowadzone postępowania egzekucyjne } \\
\text { ulegają zawieszeniu, a wszczęcie egzekucji } \\
\text { jest niedopuszczalne } \\
\text { - Wierzyciele mogą też w trakcie postępo-- } \\
\text { wania na etapie przesądowym wypowiadać } \\
\text { umowy, w tym umowy o udzielenie finanso- } \\
\text { wania oraz umowy najmu lub dzierżawy } \\
\text { - Dodatkowo, wybór nadzorcy układu oraz } \\
\text { ustalenie dnia układowego nie ma wpływu } \\
\text { na zwolnienie zarządu dłużnika (członka } \\
\text { zarządu spółki kapitałowej) z odpowiedzial- } \\
\text { ności odszkodowawczej. Nie wstrzymuje też } \\
\text { rozpoznania wniosku upadłościowego zło- } \\
\text { żonego przez wierzycieli }\end{array}$ \\
\hline
\end{tabular}


- Nadzorca układu staje się nadzorcą wykonania układu po jego prawomocnym zatwierdzeniu. Wierzyciele dysponują więc narzędziami kontroli nad dłużnikiem

- Postępowanie to doskonale nadaje się do zawarcia układu częściowego, szczególnie z wierzycielami finansowymi
- Obserwuje się też brak zaufania przez wierzycieli do wybranego przez dłużnika nadzorcy - jest on często postrzegany jako pełnomocnik dłużnika, realizujący jego interes

- Pewnym ograniczeniem jest w tym postępowaniu czas, bowiem dłużnik ma tylko trzy miesiące od ustalonego dnia układowego na zebranie głosów i przygotowanie wraz $\mathrm{z}$ nadzorcą układu wniosku do sądu o zatwierdzenie układu. Jeżeli struktura wierzytelności jest rozproszona, termin ten może okazać się za krótki na uzyskanie głosów

- Dla zatwierdzenia układu wymagana większość kapitałowa to $2 / 3$ wierzycieli uprawnionych do głosowania nad układem w pozostałych postępowaniach restrukturyzacyjnych większość ta liczona jest od sumy wierzycieli głosujących. Układ zatem może nie zostać przyjęty, gdy ponad $1 / 3$ wierzycieli będzie biernych bądź zagłosuje przeciwko. Jest to negatywne dla aktywnych wierzycieli, którzy porozumieli się z dłużnikiem

- Wierzyciele nie mają środków odwoławczych w zakresie spisu wierzytelności, który nie stanowi również tytułu egzekucyjnego. Mogą oni co najwyżej składać pisemne zastrzeżenia co do zgodności z prawem przebiegu samodzielnego zbierania głosów lub wskazania innych okoliczności, które mogą mieć wpływ na zatwierdzenie układu

\begin{tabular}{|c|c|}
\hline \multicolumn{2}{|c|}{ Przyspieszone postępowanie układowe } \\
\hline Zalety & Wady \\
\hline $\begin{array}{l}\text { - Dłużnik już z dniem otwarcia postępowania } \\
\text { uzyskuje ochronę majątku w postaci } \\
\text { zawieszenia postępowań egzekucyjnych } \\
\text { dotyczących wierzytelności objętych z mocy } \\
\text { prawa układem, a ich wszczęcie po otwarciu } \\
\text { postępowania jest niedopuszczalne } \\
\text { - Postępowania egzekucyjne dotyczące } \\
\text { wierzytelności nieobjętych z mocy prawa } \\
\text { układem mogą zostać zawieszone na } \\
\text { okres trzech miesięcy, a wierzyciel } \\
\text { zabezpieczony rzeczowo na majątku } \\
\text { dłużnika może po upływie tego } \\
\text { okresu prowadzić egzekucję wyłącznie } \\
\text { z przedmiotu zabezpieczenia } \\
\text { - Krótki czas trwania postępowania } \\
\text { pozwala uniknąć stygmatyzacji dłużnika } \\
\text { związanej z występowaniem w obrocie } \\
\text { pod dotychczasową firmą z dodaniem } \\
\text { oznaczenia „w restrukturyzacji” } \\
\text { - Możliwość wyrażenia przez nadzorcę } \\
\text { zgody na czynności przekraczające zakres } \\
\text { zwykłego zarządu ex post, co eliminuje }\end{array}$ & $\begin{array}{l}\text { - Presja wynikająca z krótkiego czasu trwania } \\
\text { postępowania - niejasna dla kontrahentów } \\
\text { i pracowników istota restrukturyzacji, } \\
\text { podszyta obawą dotyczącą ich własnej } \\
\text { sytuacji, może spowodować ich odsunięcie } \\
\text { się od dłużnika, w czasie, w którym } \\
\text { najbardziej potrzebuje on korzystnych } \\
\text { i wiarygodnych wyników finansowych, } \\
\text { które wzbudzą zaufanie wierzycieli co } \\
\text { do możliwości zrealizowania układu } \\
\text { - Brak ochrony dłużnika po upływie okresu } \\
\text { zawieszenia postępowań egzekucyjnych } \\
\text { - wierzyciele zabezpieczeni rzeczowo } \\
\text { na majątku dłużnika mogą prowadzić } \\
\text { egzekucję z przedmiotu zabezpieczenia, } \\
\text { który jest niezbędny dla prowadzonej przez } \\
\text { niego działalności } \\
\text { - Wyeliminowanie instytucji sprzeciwu co } \\
\text { do umieszczenia wierzytelności w spisie } \\
\text { wierzytelności, przez co wierzyciele nie } \\
\text { mogą kwestionować jej wysokości lub } \\
\text { pominięcia }\end{array}$ \\
\hline
\end{tabular}




\begin{tabular}{|c|c|}
\hline $\begin{array}{l}\text { ryzyko zatorów decyzyjnych w toku bieżącej } \\
\text { działalności oraz opóźnień w regulowaniu } \\
\text { większych płatności wobec kontrahentów } \\
\text { - Wierzyciele znacznie szybciej uzyskują } \\
\text { decyzję w przedmiocie przyjęcia } \\
\text { i zatwierdzenia układu, a zatem znacznie } \\
\text { szybciej mogą uzyskać korzyści płynące } \\
\text { z układu lub podjąć zawieszone } \\
\text { postępowania egzekucyjne }\end{array}$ & $\begin{array}{l}\text { - Zbyt długi czas „zawieszenia” pomiędzy } \\
\text { nieprawomocnym postanowieniem } \\
\text { o umorzeniu nieudanego postępowania } \\
\text { restrukturyzacyjnego a ogłoszeniem } \\
\text { upadłości }\end{array}$ \\
\hline \multicolumn{2}{|c|}{ Postępowanie układowe } \\
\hline Zalety & Wady \\
\hline $\begin{array}{l}\text { - Fakt, że zasadniczo zarząd nad } \\
\text { przedsiębiorstwem powinien pozostać } \\
\text { w rękach dłużnika i jedynie w wyjątkowych } \\
\text { sytuacjach zostanie on przez sąd przekazany } \\
\text { w ręce zarządcy } \\
\text { - Z chwilą otwarcia postępowania } \\
\text { układowego zawieszeniu ulegają } \\
\text { postępowania egzekucyjne dotyczące } \\
\text { wierzytelności objętych układem. Nowych } \\
\text { egzekucji wszczynać nie można. Jest to } \\
\text { niewątpliwie regulacja korzystna, gdyż } \\
\text { pozwala dłużnikowi na prowadzenie } \\
\text { w niezakłóconych warunkach negocjacji } \\
\text { z wierzycielami, celem wynegocjowania } \\
\text { optymalnego sposobu restrukturyzacji } \\
\text { zadłużenia } \\
\text { - Wierzyciele mają realny wpływ na } \\
\text { przebieg postępowania w ramach rady } \\
\text { wierzycieli, którą sędzia-komisarz może } \\
\text { powołać zarówno z urzędu, jak i na } \\
\text { wniosek dłużnika lub co najmniej trzech } \\
\text { wierzycieli lub wierzyciela albo wierzycieli } \\
\text { mających łącznie co najmniej jedną piątą } \\
\text { część sumy wierzytelności. Zadaniem rady } \\
\text { jest między innymi kontrola czynności } \\
\text { nadzorcy sądowego oraz udzielanie zgody } \\
\text { na dokonanie czynności, które mogą być } \\
\text { dokonane tylko za zezwoleniem rady } \\
\text { wierzycieli. Rada wierzycieli wydaje również } \\
\text { opinie na żądanie sędziego-komisarza, } \\
\text { nadzorcy sądowego albo dłużnika }\end{array}$ & $\begin{array}{l}\text { - Postępowanie układowe nie jest } \\
\text { wszczynane wobec dłużników tak } \\
\text { często jak przyspieszone postępowanie } \\
\text { układowe i postępowanie sanacyjne. } \\
\text { Najprawdopodobniej wynika to z faktu, } \\
\text { że przepisy dotyczące tego postępowania } \\
\text { nie przewidują korzyści oferowanych } \\
\text { dłużnikom w innych procedurach } \\
\text { - Postępowania układowego nie można } \\
\text { przeprowadzić tak szybko jak (w założeniu) } \\
\text { przyspieszonego postępowania układowego } \\
\text { ani też nie zapewnia ono tak szerokich } \\
\text { możliwości głębokiej restrukturyzacji } \\
\text { przedsiębiorstwa dłużnika jak } \\
\text { postępowanie sanacyjne (np. odstąpienie } \\
\text { od niekorzystnych umów czy zwalnianie } \\
\text { pracowników) }\end{array}$ \\
\hline \multicolumn{2}{|c|}{ Postępowanie sanacyjne } \\
\hline Zalety & Wady \\
\hline $\begin{array}{l}\text { - Niedopuszczalność skierowania egzekucji } \\
\text { do majątku dłużnika wchodzącego w skład } \\
\text { masy sanacyjnej, również egzekucji } \\
\text { zobowiązań nieobjętych układem - w tym } \\
\text { powstałych po otwarciu sanacji oraz } \\
\text { zabezpieczonych rzeczowo }\end{array}$ & $\begin{array}{l}\text { - Niedopuszczalność egzekucji wywołuje } \\
\text { obawę przed współpracą z dłużnikiem } \\
\text { i wymusza rozwiązania takie, jak żądanie } \\
\text { przedpłat, co z kolei znacznie utrudnia } \\
\text { prowadzenie bieżącej działalności } \\
\text { gospodarczej i utrzymanie płynności }\end{array}$ \\
\hline
\end{tabular}


- Możliwość odstąpienia od niekorzystnych dla przedsiębiorcy kontraktów bez względu na określony w nich tryb zmierzający do wcześniejszego rozwiązania danego kontraktu

- Możliwość rozwiązania umów o pracę bez ograniczeń podmiotowych, co umożliwia racjonalizację struktury zatrudnienia i pozostawienie kadry niezbędnej do prawidłowego działania przedsiębiorstwa (np. dopuszczalność wypowiedzenia umów o pracę pracownikom korzystającym z ochrony przedemerytalnej)

- Możliwość ubezskutecznienia czynności prawnych dokonanych przez dłużnika w ciągu roku przed dniem złożenia wniosku sanacyjnego, np. ustanowienia zabezpieczeń na jego majątku mimo braku bezpośredniego związku z otrzymaniem przez dłużnika świadczenia, dzięki czemu majątek sanowanego przedsiębiorcy jest zwalniany z nieracjonalnych ekonomicznie zabezpieczeń

- Możliwość ubezskutecznienia tzw. „nadzabezpieczenia”, czyli sytuacji ustanowienia na składnikach masy sanacyjnej zabezpieczeń o wartości wyższej niż 150\% wysokości wierzytelności w chwili ustanowienia zabezpieczenia, co pozwala przywrócić równowagę w sytuacji poszczególnych wierzycieli

- Możliwość sprzedaży składników majątku dłużnika ze skutkiem egzekucyjnym, tj. w stanie wolnym od obciążeń, co ułatwia zbycie zbędnych składników majątku
- Utrata pełnej kontroli nad przedsiębiorstwem przez ograniczenie lub nawet pełne odebranie zarządu własnego dłużnika

- Faktyczna niemożność pozyskania nowego finansowania w sektorze bankowym

Źródło: Zimmerman, Filipiak (2018: 23-31)

Znowelizowane prawo upadłościowe skupia się na jednostkach, w których istnieje zagrożenie kontynuacji działania, a w efekcie tego postępowania następuje ich likwidacja.

Postępowanie restrukturyzacyjne ma na celu przeprowadzenie restrukturyzacji zobowiązań pieniężnych dłużnika, a w postępowaniu sanacyjnym - także restrukturyzacji zatrudnienia i przedsiębiorstwa dłużnika. Ponadto rozwiązanie to pozwala na kontynuowanie działalności przez niewypłacalnego lub zagrożonego niewypłacalnością przedsiębiorcy, a tym samym zwiększa szansę na odzyskanie wymaganych zobowiązań przez wierzycieli oraz pozwala na zachowanie miejsc pracy i realizację kontraktów biznesowych.

\section{Analiza upadłości przedsiębiorstw w Polsce w latach 2001-2018}

O znaczeniu upadłości we współczesnej gospodarce świadczą skala tego zjawiska i fakt uwzględniania skuteczności postępowań upadłościowych w ocenie sprawności działalności gospodarek narodowych. Chociaż upadłości nie są zjawiskiem masowym, to występują na tyle często, że nie mogą być uznawane za zjawiska nieistotne (Mazurek, 2013). 
Potwierdzeniem znaczącej skali zjawiska upadłości są statystyki dotyczące upadłości zaprezentowane w poniższych tabelach.

Tabela 3. Liczba i struktura rodzajowa upadłości przedsiębiorstw w Polsce w latach 2001-2015

\begin{tabular}{|c|c|c|c|c|c|}
\hline \multirow{2}{*}{ Lata } & \multirow{2}{*}{\begin{tabular}{c} 
Liczba \\
\cline { 3 - 6 }
\end{tabular}} & \multicolumn{5}{|c|}{ W tym: } \\
\cline { 3 - 6 } & & upadłość likwidacyjna & \multicolumn{2}{c|}{ upadłość układowa } \\
\cline { 3 - 6 } & liczba & $\begin{array}{c}\text { udział ogółem } \\
\mathbf{( \% )}\end{array}$ & liczba & $\begin{array}{c}\text { udział ogółem } \\
\text { (\%) }\end{array}$ \\
\hline 2001 & 1674 & 1180 & 70 & 494 & 30 \\
\hline 2002 & 1863 & 1449 & 78 & 414 & 22 \\
\hline 2003 & 1761 & 1150 & 65 & 611 & 35 \\
\hline 2004 & 1116 & 889 & 80 & 227 & 20 \\
\hline 2005 & 793 & 637 & 80 & 156 & 20 \\
\hline 2006 & 576 & 480 & 83 & 96 & 17 \\
\hline 2007 & 447 & 377 & 84 & 70 & 16 \\
\hline 2008 & 411 & 348 & 85 & 63 & 15 \\
\hline 2009 & 691 & 572 & 83 & 119 & 17 \\
\hline 2010 & 655 & 538 & 82 & 117 & 18 \\
\hline 2011 & 723 & 620 & 86 & 103 & 14 \\
\hline 2012 & 877 & 711 & 81 & 166 & 19 \\
\hline 2013 & 883 & 718 & 81 & 165 & 19 \\
\hline 2014 & 823 & 701 & 87 & 122 & 13 \\
\hline 2015 & 750 & 649 & 86 & 101 & 14 \\
\hline Ogółem & 14043 & 11019 & 78 & 3024 & 22 \\
\hline
\end{tabular}

Źródło: Wydział Statystycznej Informacji Zarządczej Departament Strategii i Funduszy Europejskich Ministerstwa Sprawiedliwości

Tabela 4. Liczba upadłości przedsiębiorstw w Polsce w latach 2016-2018

\begin{tabular}{|l|c|c|c|c|c|c|}
\hline \multicolumn{7}{|c|}{ Liczba postępowań upadłościowych } \\
\hline Wyszczególnienie & $\mathbf{2 0 1 6}$ r. & $\begin{array}{c}\text { Struktura } \\
\text { (\%) }\end{array}$ & $\mathbf{2 0 1 7}$ r. & $\begin{array}{c}\text { Struktura } \\
\text { (\%) }\end{array}$ & $\mathbf{2 0 1 8}$ r. & $\begin{array}{c}\text { Struktura } \\
\text { (\%) }\end{array}$ \\
\hline $\begin{array}{l}\text { liczba postępowań } \\
\text { upadłościowych }\end{array}$ & 394 & 65,02 & 243 & 41,12 & 150 & 24,40 \\
\hline $\begin{array}{l}\text { liczba postępowań } \\
\text { restrukturyzacyjnych }\end{array}$ & 212 & 34,98 & 348 & 58,88 & 465 & 75,60 \\
\hline Ogółem & 606 & 100,00 & 591 & 100,00 & 615 & 100,00 \\
\hline
\end{tabular}

Źródło: opracowanie własne na postawie danych Centralnego Ośrodka Informacji Gospodarczej

Analiza została przeprowadzona $\mathrm{z}$ uwzględnieniem obowiązujących regulacji prawnych, z podziałem na dwa okresy: 2001-2015 oraz 2016-2018.

W latach 2001-2015 w polskiej gospodarce (tabela 3) odnotowano łącznie 14043 upadłości przedsiębiorstw, przy czym ogłoszono 11019 upadłości likwidacyjnych, co stanowiło ponad $78 \%$ ogółu upadłości w gospodarce polskiej w analizowanym okresie, oraz 3024 upadłości układowych, co stanowiło tylko niecałe 22\% ogółu upadłości. 
Tabela 5. Rodzaj i struktura postępowania restrukturyzacyjnego w gospodarce polskiej w latach 2016-2018

\begin{tabular}{|c|c|c|c|c|c|c|}
\hline \multirow[b]{2}{*}{$\begin{array}{l}\text { Rodzaj postępowania } \\
\text { restrukturyzacyjnego }\end{array}$} & \multicolumn{2}{|c|}{$2016 r$. } & \multicolumn{2}{|c|}{2017 r. } & \multicolumn{2}{|c|}{2018 r. } \\
\hline & 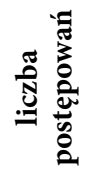 & 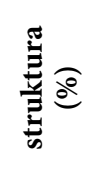 & 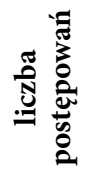 & 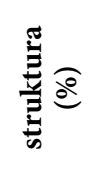 & 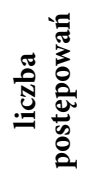 & 粷 \\
\hline $\begin{array}{l}\text { Przyspieszone } \\
\text { postępowanie } \\
\text { układowe }\end{array}$ & 134 & 63,21 & 198 & 56,90 & 294 & 63,23 \\
\hline $\begin{array}{l}\text { Postępowanie } \\
\text { sanacyjne }\end{array}$ & 48 & 22,64 & 87 & 25,00 & 121 & 26,02 \\
\hline $\begin{array}{l}\text { Postępowanie } \\
\text { układowe }\end{array}$ & 30 & 14,15 & 53 & 15,23 & 46 & 9,89 \\
\hline $\begin{array}{l}\text { Postępowanie } \\
\text { o zatwierdzeniu układu }\end{array}$ & - & - & 10 & 2,87 & 4 & 0,86 \\
\hline Ogółem & 212 & 100,00 & 348 & 100,00 & 465 & 100,00 \\
\hline
\end{tabular}

Źródło: opracowanie własne na postawie danych Centralnego Ośrodka Informacji Gospodarczej

W analizowanym okresie wyróżnić można trzy charakterystyczne podokresy, różniące się kierunkiem i dynamiką zmian zjawiska upadłości przedsiębiorstw. Pierwszy z nich obejmował lata 2001-2003, w których zjawisko to wystąpiło ze szczególnie dużym natężeniem. Odnotowano bowiem łącznie 5298 upadłości, tj. aż 37,7\% upadłości z całego okresu 2001-2015.

W latach 2004-2008 liczba upadłości przedsiębiorstw systematycznie spadała (tabela 3), z poziomu 1116 (w 2004 r.) do 411 (w 2008 r.), a tempo spadku liczby upadłości było w tym okresie silniejsze niż w okresie poprzednim, związanym $z$ dynamicznym wzrostem tego zjawiska. Trzeci podokres to powrót do wzrostu natężenia liczby upadłości.

Po 2008 r. w krajowej gospodarce upadły 5402 przedsiębiorstwa (lata 2009-2015), jednak mimo światowego kryzysu dynamika tego zjawiska nie była, w stosunku do lat 20002003, bardzo silna, niemniej wyznaczyła dość wyraźną i trwałą tendencję wzrostową.

W ramach realizowanych postępowań upadłościowych w gospodarce polskiej przeważały upadłości likwidacyjne (tabela 3), które polegały na sprzedaży majątku niewypłacalnego przedsiębiorcy oraz zaspokojeniu roszczeń wierzycieli z pieniędzy pozyskanych ze sprzedaży masy upadłościowej. Udział upadłości w celu likwidacji majątku w ogólnej strukturze postępowań upadłościowych wahał się w analizowanym okresie w granicach 65-87\% (tabela 3).

Upadłości układowe w gospodarce polskiej w latach 2001-2015, które dawały przedsiębiorstwu szansę na restrukturyzację, stanowiły około 13-35\% wszystkich postępowań (tabela 3).

E. Mączyńska na podstawie przeprowadzonych badań stwierdziła, że prawo upadłościowe i naprawcze w gospodarce polskiej w latach 2003-2015 (Mączyńska, 2008, 2009, 2011):

- nie gwarantowało przejrzystości i sprawności procedur upadłościowych,

- nie spełniło prawidłowo funkcji oczyszczania z rynku z jednostek niewypłacalnych, 
- nie przeciwdziałało w należytym stopniu upadłościom „reżyserowanym”, tj. ukierunkowanym na korzyści wąskiej grupy interesariuszy z umyślnym naruszeniem interesów wierzycieli,

- sprawiało, że w praktyce wbrew założeniom postępowania upadłościowego aspekty upadłościowe dominowały, zaś aspekty naprawcze były marginalizowane.

Od 2016 r. na skutek wejścia w życie Prawa restrukturyzacyjnego spadła liczba postępowań upadłościowych (likwidacyjnych), a wzrosła liczba postępowań restrukturyzacyjnych (tabela 4), co należy ocenić pozytywnie. Jeżeli chodzi o rodzaj postępowań (tabela 5), to dłużnicy najczęściej występowali o restrukturyzację w ramach przyspieszonego postępowania układowego - 134 postępowań w 2016 r., 198 postępowań w 2017 r. i 294 w 2018 r.

\section{Wnioski}

Problem trafności wyboru między likwidacją przedsiębiorstwa a jego restrukturyzacją jest jednym z głównych tematów zainteresowania praktyków i teoretyków zajmujących się upadłością przedsiębiorstw. Sens ekonomiczny instytucji upadłości sprowadza się do utrzymania przedsiębiorcy czasowo przeżywającego utratę płynności finansowej albo likwidacji przedsiębiorcy trwale niezdolnego do regulowania swoich zobowiązań.

Prawidłowo określone cele w prawie upadłościowym oraz w prawie restrukturyzacyjnym, dostosowane do potrzeb życia gospodarczego, mogą ułatwić prowadzenie działalności gospodarczej, ponieważ z jednej strony gwarantują szybki powrót środków produkcji w przypadku nierentowności przedsięwzięcia gospodarczego, a z drugiej zaś - w sytuacji przejściowych trudności powinny sprzyjać działaniom mającym na celu restrukturyzację zadłużenia lub też restrukturyzację przedsiębiorstwa.

Niniejsza publikacja może być przyczynkiem do dalszych badań w tym zakresie. O znaczeniu upadłości we współczesnej gospodarce świadczą skala i dynamika tego zjawiska oraz fakt uwzględniania skuteczności postępowań upadłościowych w ocenie sprawności działalności gospodarek narodowych. Z tego względu autorzy uważają, iż w przyszłości zasadne byłoby przeprowadzenie badań dotyczących efektywności polskiego systemu upadłościowego $\mathrm{w}$ aspekcie sformułowania odpowiedzi dotyczących takich zagadnień, jak:

- analiza skali procesu upadłościowego w gospodarce polskiej z uwzględnieniem przestrzennej analizy zjawiska upadłości, aspektu branżowego zjawiska upadłości, skali upadłości $z$ uwzględnieniem form prawnych,

- analiza struktury rodzajów postępowań upadłościowych w gospodarce polskiej (upadłości likwidacyjnej, upadłości restrukturyzacyjnej) na tle krajów Unii Europejskiej,

- analiza rodzaju modeli postępowań upadłościowych dominujących w gospodarce polskiej to jest modelu przyjaznego wierzycielom, czy też modelu przyjaznego dłużnikom, czy też występowania modelu mieszanego,

- analiza wpływu czynników makroekonomicznych i mikroekonomicznych na skalę i dynamikę upadłości przedsiębiorstw w gospodarce polskiej,

- analiza zmian przepisów prawa dotyczących postępowań upadłościowych, w celu podniesienia efektywności postępowań upadłościowych w gospodarce polskiej,

- analiza wpływu wdrażana w krajach Unii Europejskiej, w tym również w gospodarce polskiej, polityki drugiej szansy na poprawę efektywności funkcjonowanie polskiego systemu upadłościowego. 
Chociaż upadłości nie są zjawiskiem masowym, to występują na tyle często, że nie mogą być uznawane za zjawiska nieistotne Potwierdzeniem znaczącej skali zjawiska upadłości są statystyki dotyczące upadłości zaprezentowane w niniejszej publikacji, dotyczące polskiej gospodarki w latach 2001-2018.

\section{Zakończenie}

Zjawisko upadłości jest nieodzownym elementem każdej gospodarki rynkowej i dotyczyć może każdego przedsiębiorstwa. Chociaż obowiązujący system polityczny, gospodarczy i prawny danego kraju wpływa na poziom oraz strukturę upadłości, to jest ona powszechna i stale towarzyszy gospodarkom narodowym.

Celowość stałego monitorowania zakresu i przyczyn upadłości przedsiębiorstw w danej gospodarce, a obecnie także w coraz większym stopniu również i gospodarstw domowych (czyli tzw. upadłości konsumenckiej) wynika przede wszystkim z faktu, że sprawny przebieg tych procesów stanowi nieodłączny element efektywnie działającej gospodarki rynkowej. Nieprzypadkowo więc sformułowane zostało stwierdzenie, że kapitalizm, w którym nie zdarzają się bankructwa i upadłości, jest jak chrześcijaństwo bez piekła. Stwierdzenie to odnosi się obecnie w coraz większym stopniu również do krajów (Adamska, Mączyńska, 2013).

Przeciwdziałanie upadłości ma zasadnicze znaczenie, gdyż stan upadłości wywołuje wiele negatywnych skutków dla przedsiębiorców oraz interesariuszy wewnętrznych i zewnętrznych. Ponadto upadłość przedsiębiorcy generuje koszty nie tylko dla kontrahentów i kooperantów. Może być przyczyną wielu kosztów społecznych, które w ocenie autorów są szczególnie ważne ze społecznego i gospodarczego punktu widzenia.

Polskie prawo dotyczące upadłości przedsiębiorstw było w latach 2001-2015 dalece niedoskonałe. Skutkiem tego było to, że likwidacja przedsiębiorstwa na podstawie prawa upadłościowego była „eutanazją uleczalnych”. Obowiązujący w Polsce model postępowania naprawczego i upadłościowego w tak zmiennych warunkach społeczno-gospodarczych zdezaktualizował się, stał się nieefektywny zarówno dla dłużników, jak i dla wierzycieli, a także rynku, był nieużyteczny, przez co, zgodnie z tezą J. Stelmacha, należało odmówić mu faktycznego istnienia (Wieczerzyńska, 2015b). Zrodziło to konieczność redefinicji modelu postępowania naprawczego i upadłościowego na taki, który pozwoli przedsiębiorcy szybko, tanio i przejrzyście wyjść z rynku oraz zapewni efektywniejszą alokację zasobów lub umożliwi skuteczną restrukturyzację jego przedsiębiorstwa, przy zachowaniu wydajności tych postępowań dla wierzycieli. Odpowiedzią na podniesione tu wyzwania są uregulowania ustawy Prawo restrukturyzacyjne. Głównym ich założeniem było wprowadzenie skutecznych instrumentów pozwalających na przeprowadzenie restrukturyzacji przedsiębiorstwa dłużnika i zapobieżenie jego likwidacji. Uzasadnieniem celu głównego jest teza, iż zachowanie przedsiębiorstwa dłużnika w wielu przypadkach jest znacznie korzystniejsze dla wierzycieli niż jego likwidacja, oznacza również zachowanie miejsc pracy oraz, co do zasady, możliwość nieprzerwanego realizowania kontraktów, a więc ma pozytywne znaczenie społeczne i gospodarcze (Wieczerzyńska, 2015b).

Polska od 2016 r. wprowadziła nowe przepisy wobec podmiotów, które znalazły się w trudnej sytuacji finansowej. Idąc za założeniami Polityki Nowej Szansy, zostały wprowadzone do systemu prawnego procedury naprawczo-oddłużeniowe, które w zależności 
od sytuacji finansowo-ekonomicznej przedsiębiorcy powinny zapewnić najwłaściwsze dla niego rozwiązanie problemu przy jednoczesnym poszanowaniu interesów wierzycieli.

Właściwe regulacje prawne oraz odpowiednie otoczenie instytucjonalne działalności gospodarczej, także w zakresie procesów upadłościowych przedsiębiorstw, wywierają pozytywny wpływ na wzrost gospodarczy i rozwój państw i społeczeństw (Morawska, 2011; Lee i in., 2011).

Z zaprezentowanych $\mathrm{w}$ artykule danych (tabele 4-5) wynika, że wraz z wprowadzeniem od 2016 r. prawa restrukturyzacyjnego wzrosła liczba postępowań restrukturyzacyjnych. Niepokojącym faktem jest, iż w 2018 r. wzrosła ogólna liczba upadłości (tabela 4), pomimo dobrej koniunktury gospodarczej w gospodarce polskiej, co należy ocenić negatywnie i co może świadczyć o zbliżającym się spowolnieniu gospodarczym.

Analizując skutki wprowadzenia Prawa restrukturyzacyjnego, warto powiedzieć o dwóch efektach (Zimmerman, Filipiak, 2018). Z jednej strony wystąpił efekt przesunięcia, czyli skorzystanie z procedury restrukturyzacji przez te firmy, które w warunkach status quo musiałyby przejść przez proces upadłościowy. Z drugiej strony wystąpił efekt kreacji, gdyż nowe prawo zachęciło do podjęcia próby restrukturyzacji wiele firm, które bez tego prawa nie zdecydowałyby się na negocjacje $z$ wierzycielami. Powód wprowadzenia nowych regulacji był właśnie taki, by zachęcać do szybszej restrukturyzacji firmy, które nie chcą wchodzić w proces upadłościowy. Jak pokazuje praktyka, z roku na rok wzrasta liczba postępowań restrukturyzacyjnych, co należy ocenić pozytywnie.

Literatura

References

Adamska, A., Mączyńska, E. (2013). Upadłości, bankructwa i naprawa przedsiębiorstw. Wybrane zagadnienia. Warszawa: Oficyna Wydawnicza SGH.

Altman, E.I. (1971). Corporate bankruptcy in America. New York: MA, Heath Lexington Books.

Altman, E.I., (1983). Why businesses fail. Journal of Business Strategy. 3, 15-21.

Antonowicz, P. (2015). Bankructwa i upadłości przedsiębiorstw. Teoria - praktyka gospodarcza - studia regionalne. Gdańsk: Wydawnictwo Uniwersytetu Gdańskiego.

Banasik, P., Morawska, S. (2016). Corporate restructuring. The directions of legislative changes Ekonomika i Organizacja Przedsiębiorstw, 1, 24-33.

Druga szansa dla przedsiębiorców. Raport z badań. (2011). Warszawa: PARP.

Famielec, J., Kożuch, M. (2018). Restrukturyzacja sektorów gospodarki i przedsiębiorstw - wybrane zagadnienia. Kraków: Fundacja Uniwersytetu Ekonomicznego w Krakowie.

Hart, O. (2000). Different Approaches to Bankruptcy. Harvard Institute of Economic Research, Discussion Paper, 1903. doi: http://dx.doi.org/10.2139/ssrn.241066

Hołda, A., Strojny, K. (2019). Determinanty upadłości przedsiębiorców w Polsce - systematyka i badanie komparatywne opinii kadry zarządzającej i syndyków. Zeszyty Teoretyczne Rachunkowości, 101(157), 9-34. doi: 10.5604/01.3001.0013.0753

Horobiowski, J. (2016). Efektywność procedur insolwencyjnych - refleksje na podstawie wyników badań aktów sądowych oraz próba nakreślenia perspektyw. Biuletyn Polskiego Towarzystwa Ekonomicznego, 4, 97-103.

Hrycaj, A. (2015). Cztery postępowania restrukturyzacyjne. Doradca restrukturyzacyjny, 1, 4-15.

Kaczmarczyk, A. (2018). Koszty w postępowaniu restrukturyzacyjnym i upadłościowym w świetle regulacji prawnych. Prace Naukowe Uniwersytetu Ekonomicznego we Wrocławiu, 524, 68-76. doi:10.15611/pn.2018.524.06

Krajewski, J., Matuszak, M., Tokarski, A. (2017). Wpływ czynników makroekonomicznych na skalę i dynamikę upadłości przedsiębiorstw. Przedsiębiorczość i Zarządzanie, tom XVIII, 7(2), 185-203. 
Kuciński, K. (2005). Powody upadłości przedsiębiorstw. W: K. Kuciński, E. Mączyńska (red.), Zagrożenie upadłością. Warszawa: Oficyna Wydawnicza SGH.

Lee, S.H., Yamakawa, Y., Peng, M.W., Barney, J.B. (2011). How do bankruptcy laws affect entrepreneurship development around the world?. Journal of Business Venturing, 26(5), 505-520.

Matuszak, M., Tokarski, A. (2016a). Upadłość i jej znaczenie w gospodarce rynkowej - podejście instytucjonalne. Prace Naukowe Wyższej Szkoły Bankowej w Gdańsku, 48, 263-279.

Matuszak, M., Tokarski, A. (2016b). Obraz i przyczyny upadłości przedsiębiorstw w województwie kujawsko-pomorskim w latach 2008-2015. Prace Naukowe Wyższej Szkoly Bankowej w Gdańsku, 48, 467-486.

Mazurek, S. (2013). Niewypłacalność i jej ustalanie. Szczecin.

Mączyńska, E. (red.). (2010). Cykle życia i bankructwa przedsiębiorstw. Warszawa: Oficyna Wydawnicza SGH.

Mączyńska, E. (red.). (2008). Bankructwa przedsiębiorstw. Wybrane aspekty instytucjonalne. Warszawa: Oficyna Wydawnicza SGH.

Mączyńska, E. (red.). (2005). Ekonomiczne aspekty upadłości przedsiębiorstw w Polsce. Warszawa: Oficyna Wydawnicza SGH.

Mączyńska, E. (2015). Bankructwa, upadłości i procesy naprawcze przedsiębiorstw. Wybrane aspekty regulacyjne. Warszawa: Oficyna Wydawnicza SGH.

Mączyńska, E. (2014). Bankructwa przedsiębiorstw - wybrane aspekty ekonomiczne i prawne. Warszawa: Oficyna Wydawnicza SGH.

Mączyńska, E., Morawska, S. (2015). Efektywność procedur upadłościowych. Bankructwa przedsiębiorstw. Katharsis i nowa szansa. Warszawa: Oficyna Wydawnicza SGH.

Mączyńska, E., Adamska, A. (2013). Upadłości, bankructwa i naprawa przedsiębiorstw. Wybrane zagadnienia. Warszawa: Oficyna Wydawnicza SGH.

Mączyńska, E., Kuciński, K. (2008). Zagrożenie upadłością. Warszawa: Oficyna Wydawnicza SGH.

Morawska, S. (red.). (2011). Modele postępowań upadtościowych $w$ Polsce i wybranych krajach UE. Warszawa: Agnieszka Wierzbicka Oficyna Prawa Polskiego.

Morawska, S. (2013). Przedsiębiorca w obliczu upadłości. Warszawa: Oficyna Wydawnicza SGH.

Prawo sprzyjajace realizacji Polityki II szansy w Polsce. Rekomendacje zmian. Ekspertyza sporzadzona na potrzeby projektu „Polityka II szansy realizowanego przez Polską Agencję Rozwoju Przedsiębiorczości. (2011). Warszawa: PARP.

Portal Centralnego Ośrodka Informacji Gospodarczej: https://www.coig.com.pl/

Prusak, B. (red.). (2007). Ekonomiczne i prawne aspekty upadłości przedsiębiorstw. Warszawa: Wydawnictwo Difin.

Rogowski, W. (2015a). Rozważania nad pojęciem upadłość przedsiębiorstwa, czyli upadłość niejedno ma imię. Studia i Prace Kolegium Zarządzania i Finansów, 142, 87-116. Warszawa: Oficyna Wydawnicza SGH.

Rogowski, W. (2015b). Przyczyny upadłości polskich przedsiębiorstw - ujęcie empiryczne. Studia i Prace Kolegium Zarządzania i Finansów, 144, 161-196. Warszawa: Oficyna Wydawnicza SGH.

Szczerbak, M. (2007). Przyczyny upadłości przedsiębiorstw i uwarunkowania organizacyjne restrukturyzacji upadłościowej [w:] B. Prusak (red.), Ekonomiczne i prawne aspekty upadłości przedsiębiorstw, Warszawa: Wydawnictwo Difin.

Tokarski, A. (2015). Kierunki ewolucji systemu upadłościowego w Polsce. Przedsiębiorczość - Edukacja, $11,244-260$.

Tokarski, A., Tokarski, M. (2018). The Influence of the Macroeconomic on the Scale and Dynamics of the Bankruptcy of Enterprises in the Polish Economy in the Years 2000-2015. Transformations in Business and Economics, 17(2), AQ (44A), 337-352.

Tokarski, A. (2018). The phenomenon of bankruptcy of enterprises in the polish economy in the years 2008-2015. In: Optimization of Organization and Legal Solutions concerning Public Revenues 
and Expenditures in Public Interest (Conference Proceedings), E. Lotko, U.K. Zawadzka-Pąk, M. Radvan (ed.). Bialystok-Vilnius: Temida 2, 403-420, doi: 10.15290/oolscprepi.2018.30

Tokarski, A., Matuszak, M. (2016). Upadłość jako instytucja gospodarki rynkowej. Przedsiębiorczość Edukacja, 12, 199-216.

Tomczak, S. (2018). Statistics on bankruptcy of companies in Poland. Management Sciences, 23(3), 3950.

Upadłości i restrukturyzacje w Polsce. Wskaźniki prognozujące trudności finansowe oraz wybrane skutki zmian w przepisach z zakresu upadłości i restrukturyzacji. (2017). Warszawa: PwC.

Ustawa z dnia 15 maja 2015 roku - Prawo restrukturyzacyjne (Dz.U. z $2015 \mathrm{nr}$ 978).

Ustawa z 28 lutego 2003 roku - Prawo upadłościowe i naprawcze (Dz.U. z $2003 \mathrm{nr} 60$, poz. 535).

Ustawa z 28 lutego 2003 roku - Prawo upadłościowe (Dz.U. z 2015, poz. 233).

Wang, C. (2006). Law and Bankruptcy: An International Comparison of Liquidation and Reorganization, Asian Financial Association / Financial Management Association, Annual Conference Proceedings. New Zealand: Auckland.

White, M. (1989). The corporate bankruptcy decision. Journal of Economic Perspectives, 3(2), 129-151.

Wieczerzyńska, B. (2015a). Prawo restrukturyzacyjne - nowoczesna regulacja zapobiegajaca likwidacji przedsiębiorstwa dłużnika. W: M. Olczyk (red.). Wybrane aspekty mezo- i mikrokonkurencyjności. Gdańsk: Politechnika Gdańska. Wydział Zarządzania i Ekonomii, 114-135.

Wieczerzyńska, B. (2015b). Prawo restrukturyzacyjne - potrzeba i ocena regulacji. Studia Ekonomiczne, Prawne i Administracyjne, 2, 58-72.

Zhang, J, Bessler, D.A, Leatham, D.J. (2013). Aggregate business failures and macroeconomic conditions: a var look at the U.S. between 1980 and 2004. Journal of Applied Economics, 1, 179-202. doi: 10.1016/S1514-0326(13)60008-2

Zimmerman, P., Filipiak, P. (2018). Restrukturyzacja w Polsce w latach 2016-2017. Warszawa: SPOTDATA.

Andrzej Tokarski, dr nauk ekonomicznych. Pracuje jako wykładowca w Instytucie Finansów na Wydziale Finansów i Zarządzania WSB w Toruniu (Polska). Jego zainteresowania badawcze koncentrują się na zagadnieniach związanych $\mathrm{z}$ oceną kondycji ekonomiczno-finansowej podmiotu gospodarczego $\mathrm{w}$ aspekcie zagrożenia kontynuacji działalności oraz upadłością przedsiębiorstw w gospodarce rynkowej. Autor lub współautor ponad stu publikacji z zakresu rachunkowości, analizy finansowej i finansów przedsiębiorstw.

Andrzej Tokarski, $\mathrm{PhD}$ (in Economics), he works as a lecturer in the Institute of Finance at the Faculty of Finance and Management WSB University in Torun (Poland). The author's research interests focus on issues related to the assessment of the financial and economic standing of the economic entity at risk for bankruptcy or when the continuity of the entity's economic activity is jeopardised in the free market economy. The author published or co-published over 100 publications in the scope of accountancy, financial analysis and corporate finance.

ORCID: 0000-0002-3209-051X

\author{
Adres/Address: \\ Wyższa Szkoła Bankowa w Toruniu \\ Wydział Finansów i Zarządzania \\ Instytut Finansów \\ ul. Młodzieżowa 31A \\ 87-100 Toruń, Polska \\ e-mail: andrzej.tokarski@wsb.torun.pl
}

Maciej Tokarski, dr nauk ekonomicznych. Pracuje jako wykładowca w Instytucie Finansów na Wydziale Finansów i Zarządzania WSB w Toruniu (Polska). Jego zainteresowania badawcze 
koncentrują się na zagadnieniach związanych z funkcjonowaniem i finansowaniem małych i średnich przedsiębiorstw w gospodarce. Autor opublikował kilkadziesiąt publikacji z zakresu finansów i rachunkowości, a także był współautorem książek na temat księgowości, strategii finansowania przedsiębiorstw oraz oceny płynności finansowej podmiotów gospodarczych. Autor jest ekspertem w zakresie oceny finansowej i ekonomicznej w ramach Regionalnego Programu Operacyjnego Województwa Kujawsko-Pomorskiego na lata 2007-2013 i 2014-2020 w Urzędzie Marszałkowskim w Toruniu.

Maciej Tokarski, $\mathrm{PhD}$ (in Economics), he works as a lecturer in the Institute of Finance at the Faculty of Finance and Management WSB University in Torun (Poland). The author's research interests focus on issues related to the functioning and financing of small and medium sized enterprises in the economy. The author has published several dozen publications in the scope of finance and accountancy, as well as he was the co-author of several books on bookkeeping procedures, strategies of financing of the businesses and the assessment of the financial liquidity of the economic entities. The author is an expert on financial and economic assessment within the framework of the Regional Operational Program of the Kujawsko-Pomorskie Voivodeship for the years 2007-2013 and 2014-2020 in the Marshal's Office in Torun.

ORCID: 0000-0001-5314-7303

\section{Adres/Address:}

Wyższa Szkoła Bankowa w Toruniu

Wydział Finansów i Zarządzania

Instytut Finansów

ul. Młodzieżowa 31A

87-100 Toruń, Polska

e-mail: maciej.tokarski@wsb.torun.pl 